\title{
A descriptive method for analysing the Kra Canal decision on maritime business patterns in Malaysia
}

\author{
Noorul Shaiful Fitri Abdul Rahman ${ }^{*}$, Nurul Haqimin Mohd Salleh ${ }^{1}$, Ahmad Fayas Ahmad Najib \\ and Venus Y. H. Lun ${ }^{2}$
}

* Correspondence: nsfitri@umt.edu.my 'Department of Maritime Management, School of Maritime Business and Management, Universiti Malaysia Terengganu, Terengganu, Malaysia Full list of author information is available at the end of the article

\begin{abstract}
The Kra Canal issue has widely been discussed by maritime players, such as policy makers, regulators, and shipping and port operators. It seems that the idea of developing the Kra Canal is most welcome due to the great savings in costs, higher levels of safety and shortened distance compared to the journey via the Strait of Malacca. This phenomenon will most likely challenge the current maritime business activities in Malaysia because the total foreign going ships that call at the main ports are expected to be reduced. Therefore, the objective of this paper is to study the possible implications of the Kra Canal decision on the changes in maritime business patterns in Malaysia by focussing on the geographical aspects and logistics distribution. A descriptive analysis method will be used together with the PESTLES analysis in addressing the research objective. Finally, the positive and negative implications of the issue discussed are highlighted. Also, future maritime business strategies are proposed after taking into consideration the reshaping of the economies because of the accessibility of this new maritime route.
\end{abstract}

Keywords: Kra Isthmus canal, Maritime business patterns, Logistics distribution, Port geographic, Maritime economy, PESTLES analysis, Descriptive analysis

\section{Introduction}

The Kra Canal (otherwise known as the Thai canal or the Kra Isthmus Canal) has been debated among journalists, the academia and politicians since the late $17^{\text {th }}$ century. Recently, Thailand and China have reported the signing of an agreement in Guangzhou, China, for developing the Kra Canal as part of the so called Maritime Silk Road (Liang and Li 2015). However, both China and Thailand have denied of any related agreement signed (Wongcha-um 2015; Ryan 2015). Kinder (2007) and Su (2015) indicated that the proposed canal will connect the Gulf of Thailand in the South China Sea directly to the Andaman Sea in the Indian Ocean and bypass the Straits of Malacca and Singapore (Fig. 1). The proposed canal project is estimated to be completed within eight to ten years at the cost of $\$ 28$ billion USD ( $\mathrm{Su} 2015)$.

The industry players in the maritime field appear to be highly receptive to the Kra Canal because the canal will enable ships to bypass the Malacca Strait thus reducing

(c) The Author(s). 2016 Open Access This article is distributed under the terms of the Creative Commons Attribution 4.0 International License (http://creativecommons.org/licenses/by/4.0/), which permits unrestricted use, distribution, and reproduction in any medium, provided you give appropriate credit to the original author(s) and the source, provide a link to the Creative Commons license, and indicate if changes were made. 


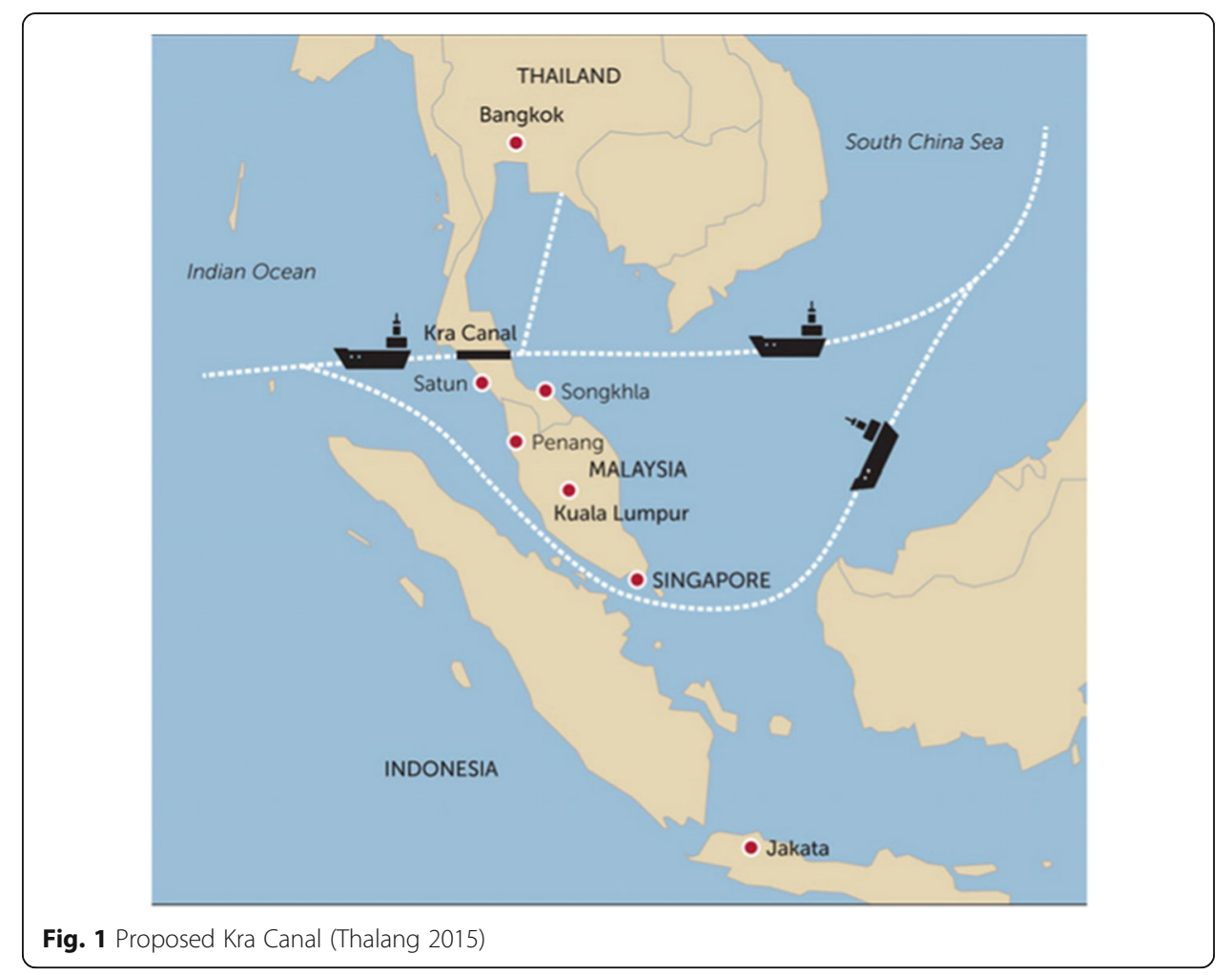

voyage distance by $1,200 \mathrm{~km}$. A shortened single journey means that ships could reduce up to $72 \mathrm{~h}$ of sailing time. Therefore, this will very likely attract the crossing of vessels. Definitely, shipping and logistics companies would welcome the reduced operating and voyaging costs between East Asia and Europe. Besides that, a shorter trip would also reduce the risk of running into pirates and avoid congestion. In addition, the length of the canal is proposed to be $102 \mathrm{~km}, 400 \mathrm{~m}$ in width and $25 \mathrm{~m}$ in depth ( $\mathrm{Su}$ 2015; Cathcart 2008). This will allow the passage of any type of cargo vessel, up to ultra large crude carriers $(300,000$ deadweight tonnage $(\mathrm{dwt}))$, or supertankers, the largest presently operating cargo vessel in the world (Gulf Times 2015). This has been verified by the Kra Canal International Forum (2014) on their website, see Fig. 2.

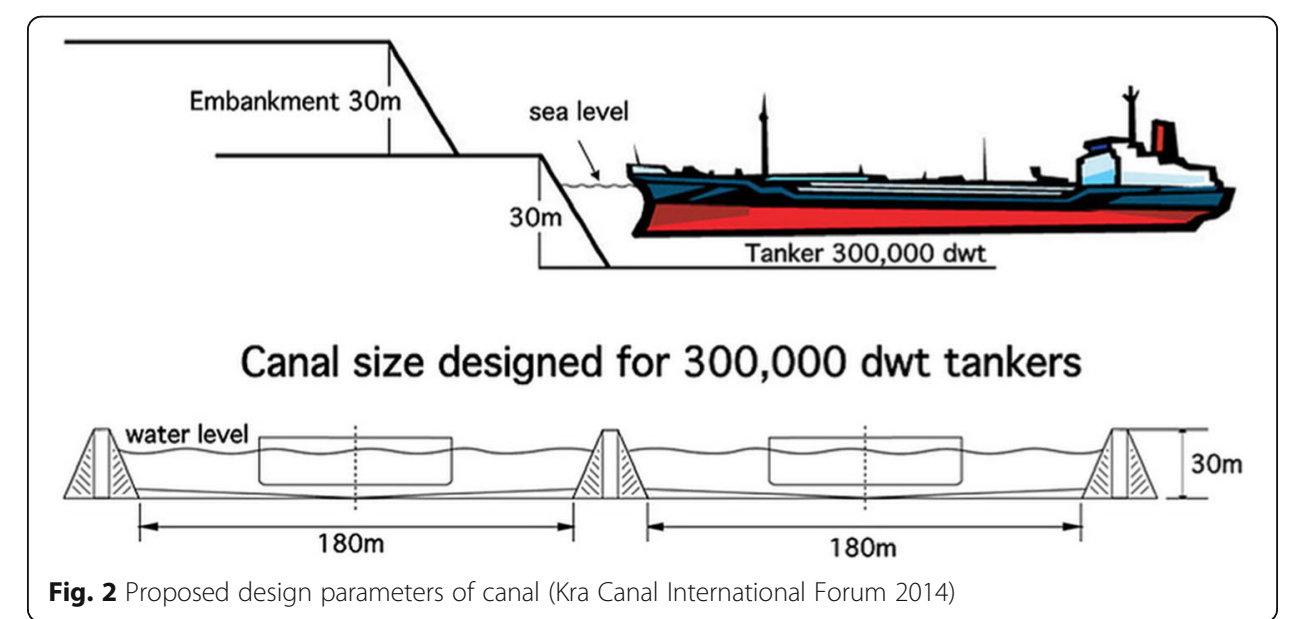


This new development will certainly change the landscape of maritime transportation in the region, if not the world. The former Prime Minister of Malaysia, Dr Mahathir Mohamad, said, "It was Thailand's right to build the canal since it is within its territories, and we just have to make adjustment. There will be reshaping of economies because of the new accessibility, then we just have to find a way how to benefit from it" (Business 2002a). Therefore, the intention of this paper is to study the possible implications of the Kra Canal decision on the changing pattern of maritime business in Malaysia by focussing on the geographical aspects and logistics distribution.

\section{Literature review}

The history of proposing the Kra Canal or Kra Isthmus Canal has been widely discussed by researchers (Khalid 2006; Kinder 2007; Cathcart 2008; Sulong 2012; Thongsin 2002; Chulikpongse 1985). The idea of developing a canal through the narrow southern end of Thailand was proposed over 200 years ago (late $19^{\text {th }}$ century) by Siamese King Narai (Min 2015). However, due to uncertain reasons (e.g., economic, political, investment or capital), the proposed project was rejected and any further discussion or action terminated. However, China and Thailand now plan to continue this project for practical reasons (e.g., economic, safety, and trade) (Su 2015; Sulong 2012; Liang and Li 2015; Thongsin 2002).

Consequently, the potential effects of the Kra Canal project on the Malaysian port and shipping sectors have been studied by national and international researchers. According to Khalid (2006), the potential effects on Malaysia are: 1) a reduction in ship traffic in the Malacca Strait, 2) a reduction in ship calls at local ports, 3) a decrease in container throughput at the local ports, 4) negative multiplier effects on the ancillary sectors, and 5) changes in trade and economic development patterns. However, the discussion is more on providing a descriptive analysis without involving any concrete and solid study. Therefore, a further study was conducted by Sulong (2012) which concerned the impact on international relations in Southeast Asia and the Association of Southeast Asian Nations (ASEAN) regional relations. It seems that the relation among the neighbouring countries will be drastically affected in terms of their economy, culture and politics. The latest study conducted by Su (2015) listed 10 global implications resultant of the proposed Kra Canal, as follows.

i. The canal will provide an alternative route in lieu of the congested Strait of Malacca.

ii. Voyage distances can be reduced by $1,200 \mathrm{~km}$ and voyage time by 2 to 5 days, thus allowing for higher vessel utilisation.

iii. The estimated bunker savings for a $100,000 \mathrm{dwt}$ oil tanker is $\$ 350,000$ per trip.

iv. Bulk shipments (e.g., oil tankers) that are chartered for direct shore to shore voyages will benefit the most.

v. Large container ships that must make frequent stops many not benefit as much - vessel capacity may not be sufficiently utilised when skipping ports in Southeast Asia.

vi. Thailand may greatly benefit from the canal toll fees, port facility charges and development in the surrounding area.

vii.Eighty percent of China's oil goes through the Strait of Malacca; the Kra Canal may reduce shipping costs and reliance on the strait, and also minimise the threat of the blockade of the strait. 
viiiSingapore's status as a maritime transhipment hub may be negatively affected with vessels bypassing the Malacca Strait all together.

ix. The ports in Hong Kong and China stand to gain from the traffic diverted from Singapore.

$\mathrm{x}$. The cost of using the canal will be a key factor.

However, the Business Times (2002a, b) reported that any effect on Malaysia will not be felt for 15 years after the completion of the canal. This argument is strongly supported with the report written by Thalang (2015) which depicted that the Kra Canal dream is still far from reality. It seems that the proposed project can still be subjected to objections with different reasons from various parties, including national and international bodies. For instance, Sulong (2012) indicated that the development of the canal will physically divide the country of Thailand and pose a security risk. Furthermore, demand for transit will not meet the expectations of the shipping companies due to the lack of facilities and market. Also, there are concerns from the environmentalists around the dredging and development activities in the surrounding area of the canal (Kra Canal International Forum 2014).

Nevertheless, the main concern for the shipping players is the capacity of the Strait of Malacca in that it is unable to accommodate more than 122,600 vessels per year (Thalang 2015). It is predicted to exceed that capacity within the next 10-15 years starting from 2015. Another alternative shipping option would be to use the Sunda Strait, which is located between the Indonesian islands of Java and Sumatra, or even the Lombok Strait, which connects the Java Sea to the Indian Ocean. However, an additional six to seven days will be added to the journey in doing so (Thalang 2015). Therefore, the proposed development of the Kra Canal is timely to overcome the congestion problem at the Malacca Strait, while shipping companies will enjoy high cost savings (in terms of fuel, and operating and voyage costs).

Another concern is the issue of security (piracy) at the Strait of Malacca. It has been reported by the International Maritime Bureau (IMB) (2013) (formally known as International Chamber of Commerce(ICC)) that the problem of piracy has been increasingly growing, with about 42 pirate attacks on vessels in 2009, 63 in 2010, 74 in 2011, 101 in 2012, and 125 in 2013. In 2013, the IMB reported a higher rate of piracy in the Malacca Straits, increasing the likelihood of insurance costs and some of the insurance companies may not be even willing to accept the risk (Nadaraj 2013). As a result, freight costs will increase and, by extension, the cargo or products shipped.

There are other factors that motivate support for the development of the Kra Canal. These are summarised in Table 1, in the form of a comparison between the Kra Canal and Strait of Malacca.

In general, the proposed Kra Canal appears to not only benefit Thailand as the host, but also the maritime players as a whole. According to the Kra Canal International Forum (2014), the benefits for shipping transportation between the Indian and Pacific Oceans by using the Kra Canal are as follows:

i. reduces transportation costs,

ii. reduces oil consumption which leads to reduce global warming,

iii. reduces vessel accidents in the Malacca Strait, 
iv. acts as an alternative route, in case the Malacca Strait is closed or has heavy traffic, and

v. new attraction pole for world direct investment that would benefit South East Asia.

In examining Table 1 and in light of the limited literature surveys, this research should be considered as a pioneer study in discussing the possible changes on maritime business patterns in Malaysia due to the proposed Kra Canal, and will focus on geographical aspects and logistics distribution.

\section{Background on study method}

\section{A generic method}

Step 1: Identification of the issues

A discussion with selected experts was carried out in this study to establish the basis of the issues based on the current situation faced by most shipping companies on concerns around maritime shipping routes. Due to the uncertainty of global business situations, for instance, 1) the instability of the global economy, 2) the unpredictability of bunker fuel prices, and 3) the imbalance between market supply and demand, most shipping companies have suffered a loss of international trade. As a result, all of the players in the shipping industry are seeking for a new means on how to solve this particular problem.

\section{Step 2: Data collection process}

There are two types of data collected, namely qualitative and quantitative data. The process of collecting both qualitative and quantitative data is as follows: the necessary

Table 1 Comparison between Strait of Malacca and Kra Canal

\begin{tabular}{|c|c|c|}
\hline Element & Strait of Malacca & Kra Canal \\
\hline Distance & $1,200 \mathrm{~km}$ longer & $1,200 \mathrm{~km}$ shorter \\
\hline Journey Time & Up to five days longer & Journey reduced by two to five days \\
\hline Safety & High rate of piracy & Possibility of Thailand separatist attacks \\
\hline Cost Saving & Less savings on cost & $\begin{array}{l}\text { Substantial savings on cost, } \\
\text { up to US\$350,000. }\end{array}$ \\
\hline Traffic System & Highly congested & $\begin{array}{l}\text { Alternative route to avoid congestion in } \\
\text { Malacca Strait }\end{array}$ \\
\hline $\begin{array}{l}\text { Business } \\
\text { Aspects }\end{array}$ & Not open to foreign direct investment & Open to foreign direct investment \\
\hline $\begin{array}{l}\text { Vessel Accident } \\
\text { and Collision }\end{array}$ & $\begin{array}{l}\text { High number of vessel accidents } \\
\text { (60 ship accidents in 2015, increased by } 25 \% \\
\text { from the previous year) (International Shipping } \\
\text { News 2016) }\end{array}$ & $\begin{array}{l}\text { Alternative route to reduce vessel accidents } \\
\text { in Malacca Straits }\end{array}$ \\
\hline Size & $\begin{array}{l}805 \mathrm{~km} \text { long, } 65-250 \mathrm{~km} \text { wide, and } 37 \mathrm{~m} \\
\text { deep (south)/200 m deep (northwest) }\end{array}$ & $\begin{array}{l}\text { The canal will be } 2 \text { way, } 102 \mathrm{~km} \text { in length, } \\
400 \mathrm{~m} \text { wide and } 25 \mathrm{~m} \text { deep. }\end{array}$ \\
\hline $\begin{array}{l}\text { Environmental } \\
\text { Pollution }\end{array}$ & Higher levels of marine and air pollutions & $\begin{array}{l}\text { Creates environmental problems due to } \\
\text { dredging and development activities } \\
\text { (marine ecosystem) } \\
\text { Potentially reduces global warming } \\
\text { (air pollution) }\end{array}$ \\
\hline $\begin{array}{l}\text { Control and } \\
\text { Monitoring } \\
\text { System }\end{array}$ & $\begin{array}{l}\text { Share with three countries } \\
\text { (Malaysia, Indonesia and Singapore). } \\
\text { Difficulties in making decisions on } \\
\text { some issues. }\end{array}$ & $\begin{array}{l}\text { Entirely under Thailand's sovereignty in } \\
\text { setting up canal policy without involving } \\
\text { other countries. }\end{array}$ \\
\hline Vessel Size & Up to Malaccamax size & Up to Ultra Large Crude Carrier (ULCC) size \\
\hline
\end{tabular}


quantitative data were obtained from the Marine Department of Malaysia (total vessel movement) and ASEAN Ports Association Malaysia (MAPA) (ship calling of foreign going vessels at the Malaysian main ports). The qualitative data were gathered through interview sessions, in which the collection process required a personal view, experience and also knowledge from the six industry experts who provided pertinent opinions on the issue discussed. An expert here is defined as an individual who has appropriate experience in the maritime transportation field, ports and is in particular involved in various aspects of shipping operations and logistics distribution for about 10 years. Further information of the six experts is shown in Table 2.

\section{Step 3: Possible implications}

Two possible changes due to the Kra Canal decision will be discussed in this part, which are: 1) geographical aspects, and 2) logistics distribution. These two aspects are important factors in contributing to the economics element on the maritime industry in Malaysia. Therefore, a question then follows, which is to ask how the Kra Canal decision will affect maritime business patterns in Malaysia.

\section{PESTLE theory and "safety and security" analysis}

PESTLE was developed by Aguilar (1967) as a tool and technique for 'scanning the business environment'. After that, small improvements to this analysis method were made by Arnold Brown for the Institute of Life Insurance (in the US) as a way to organise the results of his environmental scanning. According to Kralj (2009), several other authors in the 1980s, such as Fahey and Narayanan (1986), Morrison and Mecca (1989), and Porter (1985), included variations of the taxonomy classifications in a variety of orders: PEST, PESTLE, STEEPLE, etc. There is no implied order or priority in any of the formats.

PESTLE analysis is a useful method to identify external factors (opportunity and threat) that affect organisations or business industries (FME 2013; Ab Talib et al. 2014; Pulaj and Kume 2013). PESTLE analysis is sometimes referred to as PEST analysis. PESTLE means P for Political, E for Economic, S for Social, $\mathrm{T}$ for Technological, L for Legal and $\mathrm{E}$ for Environmental (Ward and Rivani 2005; Mohamed et al. 2010). It gives a bird's eye view of the whole environment from many different angles that one wants to check and keep track of while contemplating on a certain idea/plan. PESTLE analysis appears practicable to most research fields and various studies have been conducted by using this method. For instance, the automobile industry ( $\mathrm{Li}$ et al. 2009), online payment services (Lao and Jiang 2009), egovernment (Yingfa and Hong 2010), logistics industry (von der Gracht and Darkow 2010), ecological studies (Li 2012), construction industry (Pulaj and Kume 2013) and maritime sector (Abdul Rahman et al. 2014). PESTLE analysis answers 6 key questions which are:

Table 2 Industrial experts' information

\begin{tabular}{llll}
\hline Expert & Current position & Sub-sector & Years of experience \\
\hline Expert 1 & Chief Operations Officer & Port Operator & More than 10 years \\
Expert 2 & General Manager & Port Authority & More than 10 years \\
Expert 3 & Senior General Manager, Fleet Management Services & Shipping company & More than 10 years \\
Expert 4 & Logistics Operations Manager & Logistics Company & More than 10 years \\
Expert 5 & Fleet Management Manager & Shipping Company & More than 10 years \\
Expert 6 & General Manager & Freight Forwarders & More than 10 years \\
\hline
\end{tabular}


Political - What are the political factors that are likely to affect the business?

Economic - What are the economic factors that will affect the business?

Sociological - What cultural aspects are likely to affect the business?

Technological - What technological changes may affect the business?

Legal - What current and impending legislation will affect the business?

Environmental- What are the environmental considerations that may affect the business?

Abdul Rahman et al. (2014) studied the implications in the opening of the Northern Sea Route (NSR) on the maritime sector of the Malaysian economy by using the PESTLE analysis template (Fig. 3).

However, PESTLE analysis does not consider the element of "safety and security" in its theory Fig 3. This discredits the theory and means that it is not strong enough to convince operational experts of its application in decision making processes. Therefore, in order to strengthen the use of PESTLE analysis in this study, "safety and security" will be fully considered (thus PESTLES analysis). Therefore, the question that addresses "safety and security" will be: What are the safety and security factors that are likely to affect the business/industry?. The element of "safety and security" is not under the political factor. Thus, such an element has to stand alone by considering the following possible areas for analysing safety and security:

- accidents,

- human errors,

- work system failures,

- technical errors,

- workload, and

- unexpected safety and security problems.

Finally, this study will consider seven elements in analysing the possible implications of the Kra Canal decision on maritime business patterns in Malaysia by using PESTLES analysis. The standard six elements are Political, Economic, Socio-culture, Technology, Legal and Environment, and the seventh element is Safety and Security.

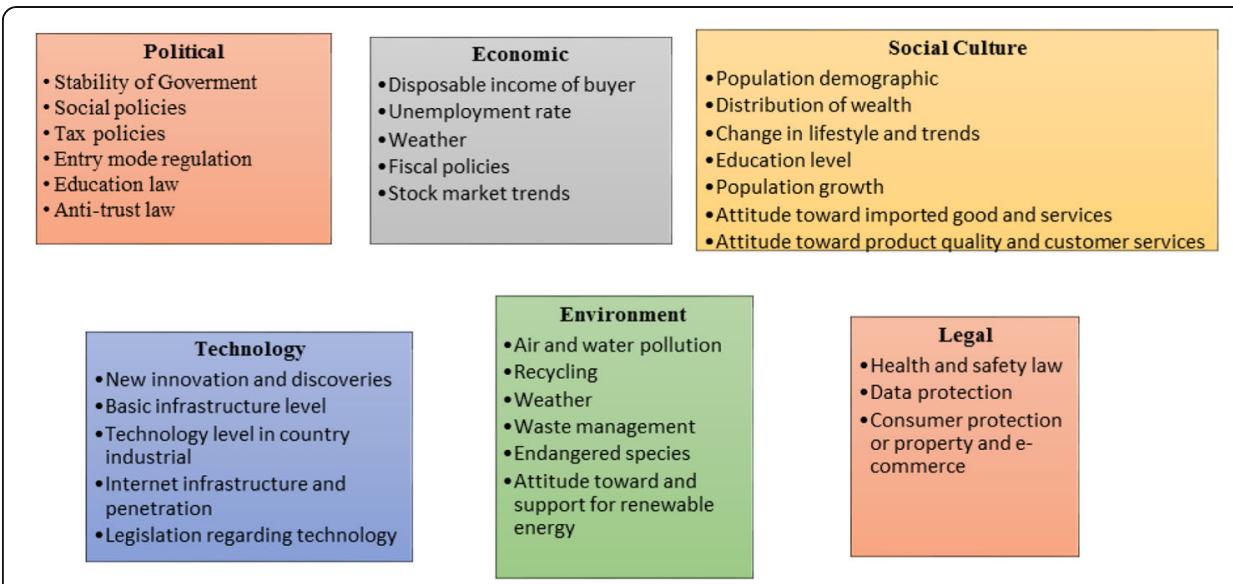

Fig. 3 PESTLE analysis template (Abdul Rahman et al. 2014) 


\section{Possible changes in maritime business patterns in Malaysia}

\section{Step 1: Identification of the issue}

The developing of the Kra Canal is a very feasible decision for most shipping companies and operators due to the many benefits and advantages that they will enjoy in its use compared to the current maritime route located at the Strait of Malacca. Therefore, the possible implications of the Kra Canal decision on changing the maritime business patterns in Malaysia will be examined by focussing on geogra phical aspects and logistics distribution with a descriptive analysis. Moreover, to strengthen the study, the PESTLES theory will be used to examine the possible implications through seven different aspects.

\section{Step 2: Data collection process}

The current maritime business patterns in Malaysia focus on the main gate by the sea which is located at Port Klang. The Strait of Malacca is considered as an international passage route for travelling between Europe and the Far East by sea and vice versa. Table 3 summarises the types of vessels and total vessel movement reported to the Klang Vessel Traffic System (VTS) from 2010 to 2014. The VTS is controlled by the Marine Department of Malaysia, Port Klang. The main types of vessels that cross the Malacca Strait are container, tanker and bulk carrier vessels. The total vessel crossing the Malacca Strait is 380,455 vessels for the five years. This shows that the number has increased every year except for a slight decrease in 2011.

From the total vessel movement shown in Table 3, only 131,689 (34.61\%) vessels were foreign going and called at the Malaysian main ports from 2010-2014. It seems that the other $65.39 \%$ just crossed the strait without giving any benefit or profit to the Malaysian ports. Even worse, any vessel collision/accident, piracy issue and marine pollution incidents have to be handled by Malaysia together with its two other neighbouring countries, Indonesia and Singapore. These issues are strongly supported by data from the total foreign going ships that called at the Malaysian main port from

Table 3 Types of vessels and total vessel movement reported to Klang VTS from 2010 to 2014

\begin{tabular}{lllllll}
\hline TYPE & 2010 & 2011 & 2012 & 2013 & 2014 & Total \\
\hline VLCC/DEEP DRAFT CR & 4333 & 4539 & 4732 & 4825 & 4993 & 23,422 \\
TANKER VESSEL & 16,247 & 16,223 & 17,345 & 18,296 & 18,765 & 86,876 \\
LNG/LPG CARRIER & 3579 & 3830 & 4014 & 4248 & 4173 & 19,844 \\
CARGO VESSEL & 8445 & 7996 & 7950 & 7613 & 6989 & 38,993 \\
CONTAINER VESSEL & 24,806 & 25,552 & 24,639 & 24,658 & 25,071 & 124,726 \\
BULK CARRIER & 11,642 & 10,851 & 11,678 & 12,658 & 13,454 & 60,283 \\
RORO/CAR CARRIER & 2624 & 2545 & 2980 & 2998 & 3146 & 14,293 \\
PASSENGER VESSEL & 1071 & 877 & 861 & 1063 & 1041 & 4913 \\
LIVESTOCK CARRIER & 45 & 47 & 38 & 55 & 59 & 244 \\
TUG/TOW VESSEL & 545 & 414 & 529 & 563 & 676 & 2727 \\
GOV/NAVY VESSEL & 37 & 57 & 50 & 58 & 96 & 298 \\
FISHING VESSEL & 20 & 20 & 52 & 27 & 51 & 170 \\
OTHER & 739 & 577 & 609 & 911 & 830 & 3666 \\
TOTAL & 74,133 & 73,528 & 75,477 & 77,973 & 79,344 & 380,455 \\
\hline
\end{tabular}

(Source: Marine Department Malaysia 2015) 
2010-2014 (Table 4). The data include several types of foreign going ships, such as containerships, general cargo ships, liquid tankers, dry bulk ships, and other ships. It has been proven from statistics that foreign going ships that call at Port Klang were reduced from 15,914 vessels in 2011 to 15,306 vessels in 2012, 14,139 vessels in 2013 to 13,377 vessels in 2014. A similar business pattern is found in the three other main ports of Penang Port, Johor Port and Port of Tanjung Pelepas. The statistics on ship calling in 2015 is expected to be reduced respectively due to an unstable global economy, market demand and political aspects in Malaysia.

Figure 4 is a plot of foreign going ship calls in Malaysia. Obviously, the plot shows the instability and reduction of foreign ships that call at Malaysia. Ultimately, this situation has affected the port profit. It seems that there are no main line container vessels calling at the Klang and Penang Ports. Only one feeder container vessel reported calling at the Penang Port for both 2013 and 2014. For the Johor port, there was no feeder container vessel and other vessels calling from 2010 to 2014. However, obviously all of the ships calling at the Port of Tanjung Pelepas are containers (main line and feeder).

\section{Step 3: Possible implications}

The possible implications on the geographical aspects and logistics distribution will be discussed in this step. All information is obtained through interview sessions with six industry experts.

Table 4 Types of foreign going vessel calls at Malaysian main ports, 2010-2014

\begin{tabular}{|c|c|c|c|c|c|c|c|c|}
\hline \multirow[t]{2}{*}{ Port } & \multirow[t]{2}{*}{ Years } & \multicolumn{2}{|l|}{ Container } & \multirow{2}{*}{$\begin{array}{l}\text { General } \\
\text { cargo }\end{array}$} & \multirow{2}{*}{$\begin{array}{l}\text { Liquid } \\
\text { tankers }\end{array}$} & \multirow{2}{*}{$\begin{array}{l}\text { Dry } \\
\text { bulk }\end{array}$} & \multirow[t]{2}{*}{ Other } & \multirow[t]{2}{*}{ Total } \\
\hline & & Main line & Feeder & & & & & \\
\hline \multirow[t]{5}{*}{ Klang } & 2010 & - & 10,751 & 1118 & 1975 & 360 & 988 & 15,192 \\
\hline & 2011 & - & 11,273 & 1249 & 2091 & 378 & 923 & 15,914 \\
\hline & 2012 & - & 10,300 & 1237 & 1902 & 398 & 1469 & 15,306 \\
\hline & 2013 & - & 9950 & 1302 & 1564 & 433 & 890 & 14,139 \\
\hline & 2014 & - & 9601 & 1228 & 1350 & 428 & 770 & 13,377 \\
\hline \multirow[t]{5}{*}{ Penang } & 2010 & - & - & 796 & 796 & 163 & 1543 & 3298 \\
\hline & 2011 & - & - & 683 & 882 & 176 & 1387 & 3128 \\
\hline & 2012 & - & - & 632 & 873 & 200 & 2257 & 3962 \\
\hline & 2013 & - & 1 & 680 & 847 & 210 & 1645 & 3383 \\
\hline & 2014 & - & 1 & 583 & 824 & 193 & 1358 & 2959 \\
\hline \multirow[t]{5}{*}{ Johor } & 2010 & 1581 & - & 426 & 1750 & 330 & - & 4087 \\
\hline & 2011 & 1320 & - & 459 & 2007 & 622 & - & 4408 \\
\hline & 2012 & 1305 & - & 457 & 1703 & 358 & - & 3823 \\
\hline & 2013 & 1094 & - & 477 & 1558 & 382 & - & 3511 \\
\hline & 2014 & 1176 & - & 321 & 1547 & 320 & - & 3364 \\
\hline \multirow[t]{5}{*}{ Tanjung Pelepas } & 2010 & 1532 & 2113 & - & - & - & - & 3645 \\
\hline & 2011 & 2137 & 2386 & - & - & - & - & 4523 \\
\hline & 2012 & 2315 & 2413 & - & - & - & - & 4728 \\
\hline & 2013 & 2542 & 1943 & - & - & - & - & 4485 \\
\hline & 2014 & 2094 & 2363 & - & - & - & - & 4457 \\
\hline TOTAL & & 17,096 & 63,095 & 11,648 & 21,669 & 4951 & 13,230 & 131,689 \\
\hline
\end{tabular}

(Source: ASEAN Ports Association Malaysia (MAPA) 2015) 


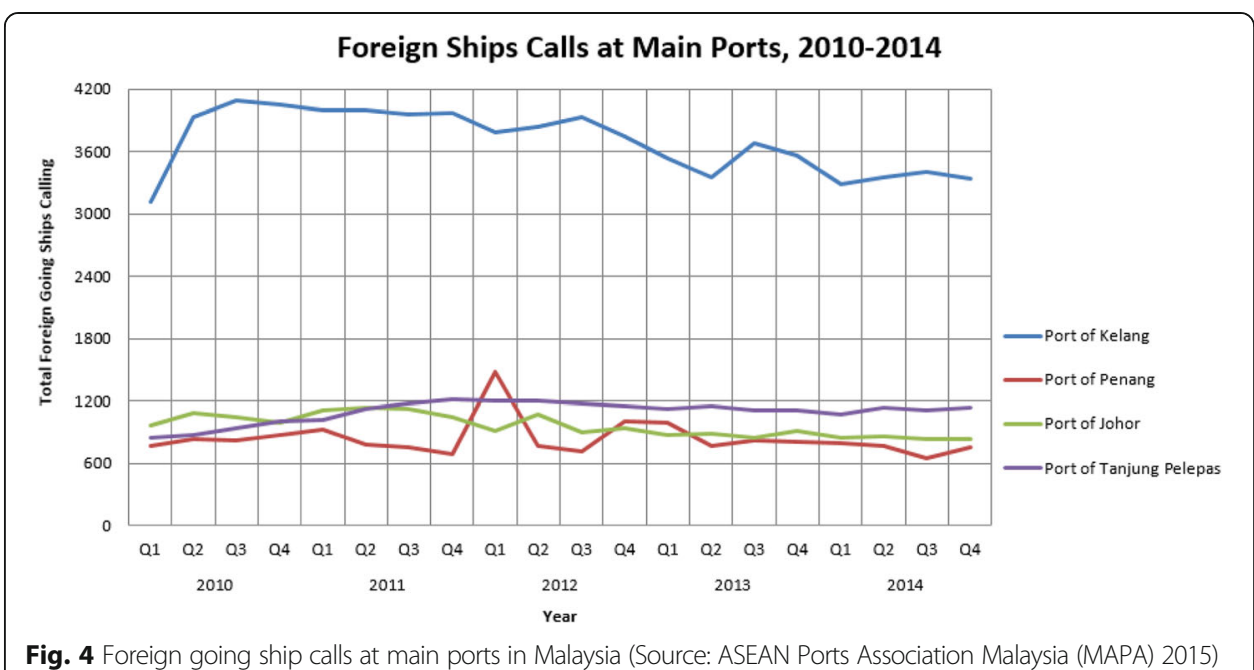

\section{a) Geographical aspects}

The changes in the geographical target will be evident. There are a minimum of six (6) possibilities of new maritime routes that can be developed after implementing the Kra Canal (Fig. 5). They are for instance:

a) Europe/Middle East - Penang - Far East (and vice versa)

b) Europe/Middle East - Penang - Bangkok - Far East (and vice versa)

c) Europe/Middle East - Satun - Far East (and vice versa)

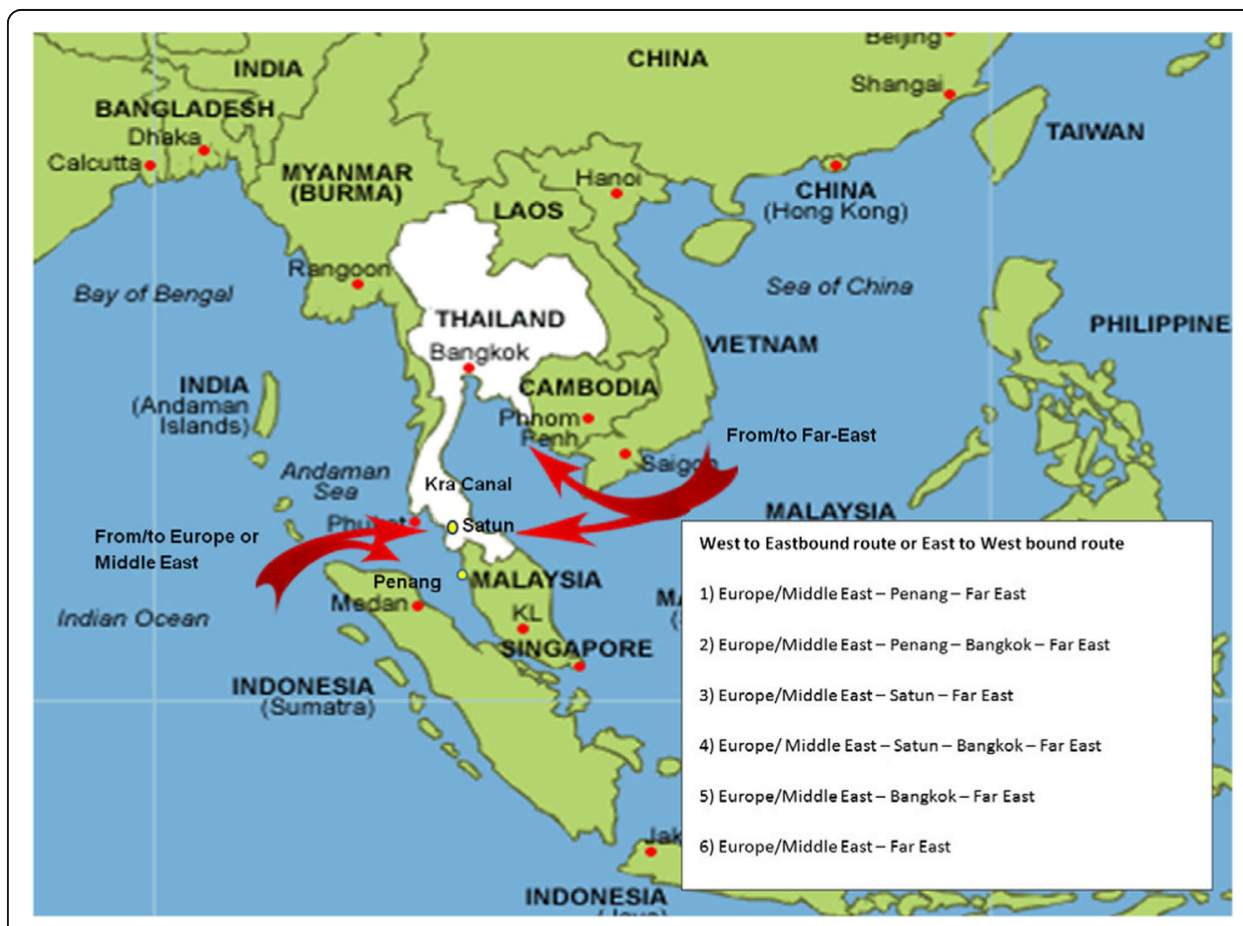

Fig. 5 New maritime routes after implementation of Kra Canal (Authors' Illustration) 
d) Europe/Middle East - Satun - Bangkok - Far East (and vice versa)

e) Europe/Middle East - Bangkok - Far East (and vice versa)

f) Europe/Middle East - Far East (and vice versa)

Obviously, the Bangkok and Penang Ports will experience significant benefits due to this mega project. In terms of the perspective of Malaysia, the Penang Port is still quite near to the canal and, perhaps, the effect may only be marginal. Also, Malaysia is still one of the target destinations to be called at by foreign going vessels. Although the port destination is expected to change due to the shifting of the route service but, Malaysia is still able to obtain economic benefits through the Penang Port. In current practice, most vessels prefer to call at Port Klang, Johor Port and Port of Tanjung Pelepas as hubs for the handling of import and export cargo as well as transhipment cargo compared to the Penang Port. However, after developing the Kra Canal, the geographical aspect of the Penang Port will be that it acts as the main gateway when entering Malaysia by sea. This situation will benefit the Penang Port from many perspectives, for instances, increases in 1) foreign going vessel ship calls, and 2) logistics and supply chain activities.

\section{b) Logistics distribution}

In practice, Port Klang, the Port of Tanjung Pelepas and Johor Port will be among the selected ports for port of call and transhipments. However, if the Kra Canal is available, it is predicted that the Penang Port will be a new shipping hub that replaces Port Klang as well as the Port of Singapore (Fig. 6). All of the feeder vessels will be operating from the Penang Port to other main ports such as Port Klang, Port of Singapore, Kuantan Port and Tok Bali Port. For the latter, feeder vessels will cross through the Kra Canal, but for the Kuantan Port, they might have two route options: either through the Kra Canal or the traditional shipping route.

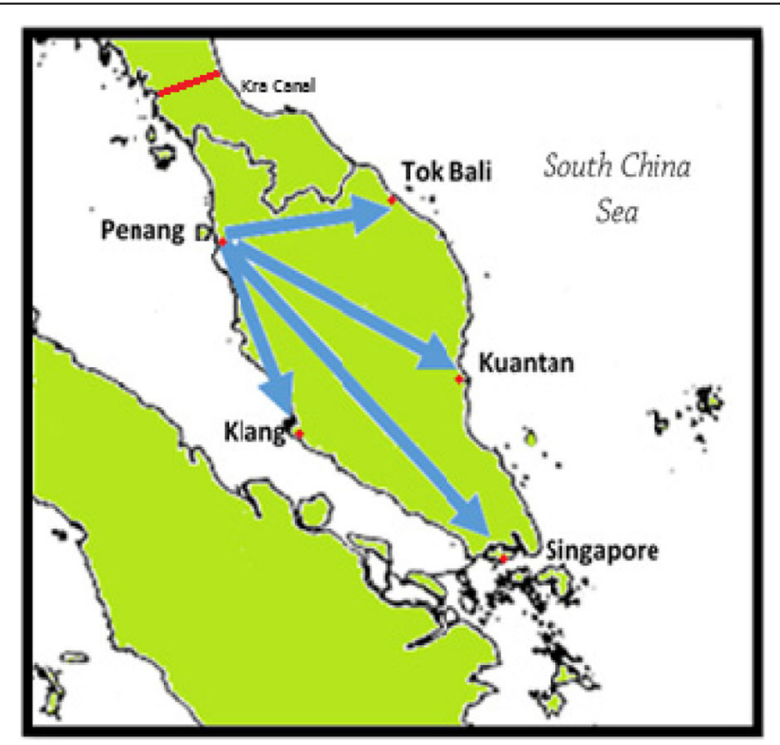

Fig. 6 Location of Penang Port as a potential new shipping hub in Malaysia (Authors' Illustration) 
Currently, the Penang Port is the main gateway for the northern Malaysian hinterland and also serves cargo transportation to and from South Thailand. It is also connected to the North-south and the East-west highways as well as to the rail network. The port is connected by road and rail to an inland terminal located at Padang Besar near the border of Malaysia-Thailand. Padang Besar inland terminal is also connected by road and rail to South Thailand which is the location of the proposed Kra Canal. Nevertheless, if the Penang Port becomes the new shipping hub, then it is possible that the hinterland radius will also be increased.

As a new shipping hub, the free trade zone in the Penang Port means that the port will be larger and more active. Many production companies will establish their factories or warehouses in this free trade zone due to fast and efficient shipping and logistics. These will provide significant opportunities to business companies as well as expand the local economy.

\section{Discussion}

\section{Positive and negative implications}

Less vessel traffic that crosses at the Strait of Malacca will have both positive and negative implications. Table 5 summarises the implications of using a PESTLE analysis that incorporates the element of "safety and security" (thus PESTLES analysis). All information is obtained through a qualitative data collection process, or interviews with industry experts.

\section{Future strategies for maritime business}

If the Kra Canal is going to be realised, Malaysia needs to find a way to benefit from the canal. Diversification of maritime business by investing in regionally strategic areas, such as Langkawi in Kedah, Padang Besar in Perlis, Penang Port, Tok Bali in Kelantan, or even in neighbouring countries, including Thailand and Myammar, appears to have the potential to increase market share despite the trade route shift. Nationally, there are three potential strategies that can be implemented in the future, which are the enhancement of the Penang Port as the hub port of Malaysia; the development of an inland depot at Padang Besar, Perlis; and the establishment of Tok Bali as a bunkering port in Kelantan.

It is anticipated that Malaysia's ports, such as the Port Klang, Johor Port and Port of Tanjung Pelepas, will lose ship calls and traffic volume, which will lead to significant losses in port business due to the Kra Canal. On the other hand, the Penang Port has an advantage as a result of its geographical location which is close to the canal. Therefore, the Penang Port can be promoted as the hub port of Malaysia. Consequently, current facilities such as berth areas (e.g., container, break bulk, dry bulk, liquid, passenger, and bunker berths), storage (e.g., warehouses, transit sheds, covered storage, and open yards), equipment (e.g., quay cranes, pilot and tug boats, trailers, prime movers, and stackers) and information technology (e.g., Electronic Data Interchange (EDI) system), need to be upgraded and significantly optimised. In addition, port efficiency also needs to be assessed and enhanced in order to provide competitive services. Collaborative research, and domestic and foreign investments should be encouraged to hasten the process.

The Indonesia-Malaysia-Thailand Growth Triangle (IMT-GT) is a programme to stimulate development in Indonesia, Malaysia and Thailand. As part of the development, an inland container depot (ICD) at Padang Besar was strategically placed at the Malaysia-Thailand border. The ICD connects with the Penang Port via two modes of 
Table 5 Positive and negative implications of Kra Canal on maritime business in Malaysia

\begin{tabular}{ll}
\hline Elements & Positive implications for Malaysia \\
\hline Political Aspects & $\begin{array}{l}\text { 1. Malaysia and Thailand will have more } \\
\text { Memorandum of Understandings } \\
\text { (MoUs) and economic cooperation if } \\
\text { the shipping hub is changed. }\end{array}$
\end{tabular}

Economic Aspects 1. Cost savings for search and rescue (SAR) activity at the Strait of Malacca.

2. Save on cleaning costs due to oil spills.

3. Penang is expected to grow very fast due to its proximity to the canal.

4. The Tok Bali Port will be potentially developed to supply bunker fuel for all vessels.

5. The economy development of both the North and East coasts of Malaysia is expected to increase due to the port change.

6. Fishery activity at the Johor Strait is expected to increase because of fewer oil spills and pollution problems.

Social Aspects

1. The social life patterns in both the North and East coasts of Malaysia are expected to be affected.

2. Fishing income in Johor is expected to increase in line with the growth of the fishery industry.

Technological Aspects

Legal and Policy Aspects

Environmental Aspects
1. The current technology at the Penang Port can be further upgraded to increase the efficiency of port operations.

These have been studied by Sulong (2012).

1. Emission and pollution along the strait will be reduced.

2. There is potential for recovering the marine habitat, biodiversity and ecosystem along the strait.

Negative implications for Malaysia

1. Trade or bilateral relation between Malaysia and other countries might change due to the movement of investment from the area that surrounds the main ports to possibly Satun or Songkhla, Thailand.

1. The Strait of Malacca will not be one of the important international venues for transporting cargo to and from Europe and the Far East.

2. Fewer foreign going vessels will call at the three main Malaysian ports.

3. Port Klang, Johor Port and Port Tanjung Pelepas are expected to experience loss in port trade revenue which directly impacts port revenue and profit.

4. Fewer ship calls mean less revenue from vessel operators, consignees and consignors due to less cargo handled by the main ports.

5. Less cargo handled means fewer import and export activities which lead to the reduction of import and export duties collected by customs.

6. Less cargo handled by the ports will affect haulage/logistics and supply chain companies which lead to less income/profit.

7. Truck surplus will follow because of low market demand.

8. Overall, there is a drop in the maritime economy and contribution to the Malaysian economy.

1. The social life patterns of the communities around the three main ports may be maintained or slightly negatively affected.

2. High unemployment rate is expected to take place due to the possible downsizing of logistics and supply chain companies.

3. If the unemployed increase in number in the surrounding areas of the three main ports, an increase in the crime rate is very much possible.

1. A large amount of investment is needed to buy high technology for ship and port operations at the Penang Port.

1. Emission and pollution are expected to increase in the north region of Malaysia (Penang, Tok Bali) due to the shipping activities in that area (oil spills can reach the Malaysian coast because of wave movement and currents).

2. There is concern about organisms/ micro-organisms and their habitat on both sides of the sea (South China and Andaman Seas) because of the difference in salinity as water flows easily through the canal (which will affect Malaysian water if the canal is built near Malaysia).

Safety and

1. Fewer vessel collisions or accidents

1. Spill over of separatist movement on northern top of Malaysia. 
transport, which are road and rail. The current volume of trade that passes through Padang Besar constitutes of $31.2 \%$ of the total exports from Southern Thailand (IMT-GT 2011). Recently, the Malaysian Prime Minister has approved funds from the federal government for RM850 million towards the development of an ICD in the Chuping Valley of the Perlis state (The Star 2015). With this development, the logistic connections between Malaysia and Thailand can be improved. It is anticipated that after the Kra Canal is realised, the trade pattern will change from southbound to northbound as a result of the Kra Canal advantages. Therefore, long-term planning for the development of this ICD should be carried out by considering the possibility of the Kra Canal. As a result, this ICD could adapt to future changes.

As bunker fuel is the main energy source for moving ships, bunker fuel supply is an important factor in the shipping industry. On the east coast of Peninsular Malaysia, the Tok Bali area can be developed as a bunkering port to offer bunkering services to vessels that cross the Kra Canal that are both eastbound and westbound. Leveraging from the existing Tok Bali special town area plan which is to set Tok Bali as a maritime port city before 2045, one industry that could be considered are bunkering facilities (Bachok District Council 2015). As shown in Fig. 7, a gas pipeline is already constructed that passes

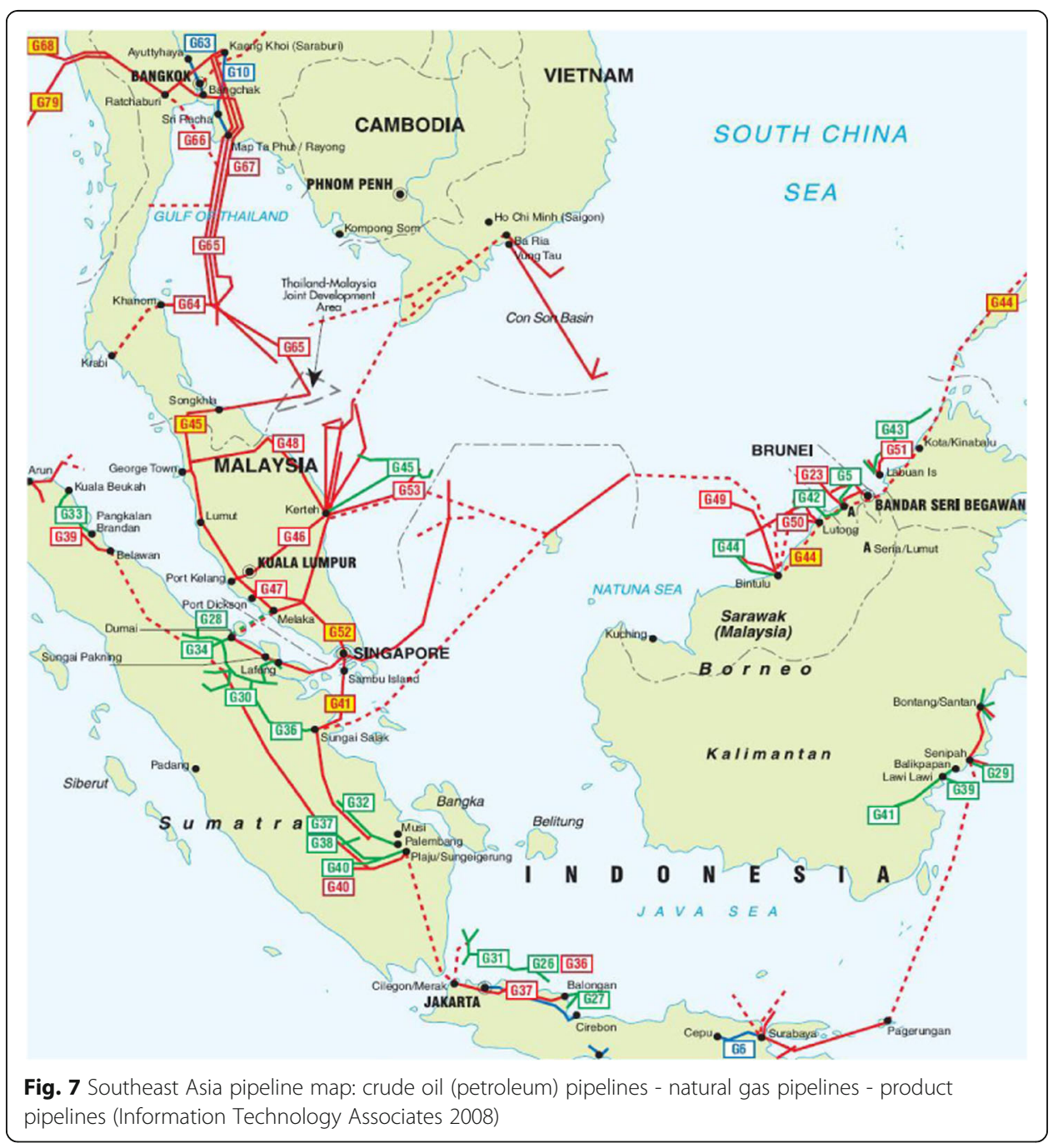


through the Tok Bali area, from Kerteh, Terengganu to Kota Bharu, Kelantan. As Kerteh is the largest oil refinery area in Malaysia, oil pipelines can be constructed to supply oil to Tok Bali in the future. Aware of this opportunity, several oil and gas companies have already invested in bunkering facilities in the area. One of the companies is Ahmad Zaki Resources Berhad, which invested RM27 million to construct three marine tanks in Tok Bali (Zheng 2015). It is expected that these bunkering facilities can attract customers from Thailand and oil production companies such as Petronas Carigali, Talisman and Hess Exploration to utilise the Tok Bali Port for future business opportunities.

\section{Conclusions}

The idea of developing the Kra Canal is most welcome by shipping practitioners because of the substantial amount of cost savings, its high level of safety and security, and reduction in journey distance of vessels. Consequently, the maritime business activity at the Malacca Strait may be significantly affected and there will be the reshaping of the economies because of the new accessible sea route. Therefore, the contributions of this research are: 1) identification of the possible changes in maritime business patterns in Malaysia, and 2) determining the positive and negative implications with the use of 7 elements in a PESTLES analysis. These seven factors are aggregated to propose a future maritime business strategy in Malaysia that can generate revenue that would boost the maritime economy, for instance: 1) diversification by maritime businesses who could invest in regionally strategic areas, 2) development of the Tok Bali area as a bunker port to offer bunkering services, and 3) promotion of the Penang Port as the hub port of Malaysia. These strategies can reshape the Malaysian economy.

Acknowledgement

A huge appreciation delivered to Universiti Malaysia Terengganu for providing fund and research facilities.

Author's contributions

All authors of this research paper have directly participated in the planning, execution, or analysis of this study. All authors read and approved the final manuscript.

Competing interests

The authors declare that they have no competing interests.

\section{Author details}

${ }^{1}$ Department of Maritime Management, School of Maritime Business and Management, Universiti Malaysia Terengganu, Terengganu, Malaysia. ${ }^{2}$ Shipping Research Centre, The Hong Kong Polytechnic University, Kowloon, Hong Kong.

Received: 13 August 2016 Accepted: 18 October 2016

Published online: 21 November 2016

References

Ab Talib MS, Abdul Hamid AB, Zulfakar MH, Jeeva AS (2014) Halal logistics PEST analysis: the Malaysia perspectives. Asian Soc Sci 10(14):119-131

Abdul Rahman NSF, Saharuddin AH, Rasdi R (2014) Effect of the Northern Sea Route opening to Malacca shipping activity at Malacca straits. International Journal of e-Navi Marit Econ 1:85-98

Aguilar FJ (1967) Scanning the business environment. Macmillan, New York

ASEAN Ports Association Malaysia (MAPA) (2015) Maritime transportation statistics in Malaysia, Annual report of 2010-2014

Bachok District Council (2015) Draft of bandar Tok Bali special area plan 2045., http://www.mdbachok.gov.my/

Business Times (2002a) KL has no qualms over proposed canal. West Publishing Company, Malaysia

Business Times (2002b) Kra canal plan not likely to hit Malaysian ports. West Publishing Company, Malaysia

Cathcart RB (2008) Kra canal (Thailand) excavation by nuclear-powered dredges. Int J Glob Environ Issues 8(3):248-255

Chulikpongse S (1985) The alternative shorter sea routes via Isthmus of Kra: the land bridge approach. Master thesis submitted to the faculty of economics and commerce, University of Tasmania

Fahey L, Narayanan V K (1986) Macroenvironmental analysis for strategic management (The west series in strategic management), St. Paul, Minnesota: West Publishing Company, West 
FME (2013) PESTLE analysis strategy skills, the fee management ebook, ISBN: 9781626209985

Gulf Times (2015) \$28Bn Kra canal to provide shipping shortcut, May, Doha

IMT-GT (2011) Indonesia-Malaysia-Thailand growth triangle., http://www.imtgt.org/

Information Technology Associates (2008) Southeast Asia pipelines map - crude oil (petroleum) pipelines - natural gas pipelines

- products pipelines., http://www.theodora.com/pipelines/southeast_asia_oil_gas_products_pipelines_map.html

International Shipping News (2016) Higher traffic in Malacca Strait raises concerns about accidents, Hellenic Shipping

News. Piraeus. http://www.hellenicshippingnews.com/higher-traffic-in-malacca-strait-raises-concerns-aboutaccidents/

Khalid N (2006) Proposed Kra canal project: potential effects on Malaysian ports and shipping Sector

Kinder I (2007) Strategic implications of the possible construction of Thai canal, Croatian International relations review. pp 109-118

Kra Canal International Forum (2014) The Kra Canal: new gateway to maritime silk road. Thai Chinese Cultural and Economic Association. Bangkok. http://www.kracanal-maritimesilkroad.com/

Kralj D (2009) Sustainable green business, Advances in marketing management and finances., pp 142-146

Lao G, Jiang S (2009) Risk analysis of third-party online payment based on PEST model, International Conference on Management and Service Science (MASS'09). IEEE, Wuhan, p. 1-5

Li J (2012) Study on practice of and measures for ecological compensation mechanism in the three Gorges reservoir area from SWOT-PEST analysis, $4^{\text {th }}$ International Conference on Computational and Information Sciences (ICCIS). IEEE, Washington, DC, p. 1353-1356

Li X, Mao Z, Qi E (2009) Study on global logistics integrative system and ke technologies of chinese automobile industry, International Conference on Management and Service Science (MASS'09). IEEE, Wuhan, p. 1-4

Liang Y, Li Z (2015) Thailand, China to team up on long-proposed Kra Isthmus canal, 18 May, Want China Times. Taipei City. https://johnib.wordpress.com/2015/05/18/thailand-china-to-team-up-on-long-proposed-kra-isthmuscanal/

Marine Department Malaysia (2015) Types of vessels and total vessel movement from 2010 to 2014, Klang VTS Annual Report. Marine Department Malaysia, Malaysia

Min CH (2015) Renewed hype over China-Thai canal project: 5 things about the Kra Canal, The Straits Times, Singapore Press Holding, Tao Payoh N, Singapore

Mohamed ZA, Ann HJ, Yee WF (2010) Strategic management. Oxford Fajar, Selangor

Morrison JL, Mecca TV (1989) Managing uncertainty. In: In Higher Education: Handbook of Theory and Research, vol 5. Agathon Press, New York, pp 334-382

Nadaraj V (2013) Piracy in the Malacca straits: pirates likely to bring quick end to historic trade route, the establishment post., http://www.neptunemaritimesecurity.com/piracy-in-the-malacca-straits-pirates-likely-to-bring-quick-end-tohistoric-trade-route/

Porter ME (1985) Competitive advantage: creating and sustaining superior performance. Free Press, New York

Pulaj E, Kume V (2013) How the Albanian external environment affect the construction industry. Annales Universitatis Apulensis-Series Oeconomica 15(1):295-309

Ryan F (2015) China denies official involvement in Thailand canal, Herald Sun., http://www.heraldsun.com.au/business/ breaking-news/china-thailand-to-build-strategic-canal/story-fnn9c0hb-1227359979272

Su S (2015) Looking ahead: the port industry - how Asean ports respond to the changing global maritime trade trends?, BMT Asia Pacific, Des Voeux Road Central, Hongkong

Sulong RS (2012) The Kra canal and Southeast Asian relation. J Curr Southeast Asian Affairs 31(4):109-125

Thalang JN (2015) Kra canal dreams still far from reality. Spectrum 7 June, the Bangkok Post., http://www.bangkokpost. com/news/special-reports/584473/kra-canal-dream-still-far-from-reality

The Star (2015) Perlis to get Mega Projects Worth RM850million., http://www.thestar.com.my/News/Nation/2015/05/31/ Perlis-to-get-mega-projects-worth-RM850mil/

Thongsin A (2002) The Kra canal and Thai security. Master thesis submitted to the Naval Postgraduate School. Monterey

Von Der Gracht HA, Darkow IL (2010) Scenarios for the logistics services industry: A Delphi-based analysis for 2025. Int J Prod Econ 127(1):46-59

Ward D, Rivani E (2005) An overview of strategy development models and the Ward-Rivani model. Papers, Economics Working

Wongcha-um P (2015) Thailand denies Kra canal deal, Channel News Asia., http://www.channelnewsasia.com/news/ asiapacific/thailand-denies-kra-canal/1856758.html

Yingfa S, Hong Y (2010) The risk study of e-governance based on PEST analysis model, International Conference on E-Business and E-Government (ICEE), Guangzhou, p. 563-566

Zheng T (2015) AZRB invests \$7.44M in bunkering facilities., http://fairplay.ihs.com/article/16472/azrb-invests-7-44mbunkering-facilities 